Transnational Business Governance Interactions Project Working Paper No. 27

April 2019

\title{
Interactions, Iteration and Early Institutionalization: Competing Lessons of GLOBALGAP's Legitimation
}

\author{
Donal Casey
}

University of Kent

This paper is available free of charge from www.tgiforum.org

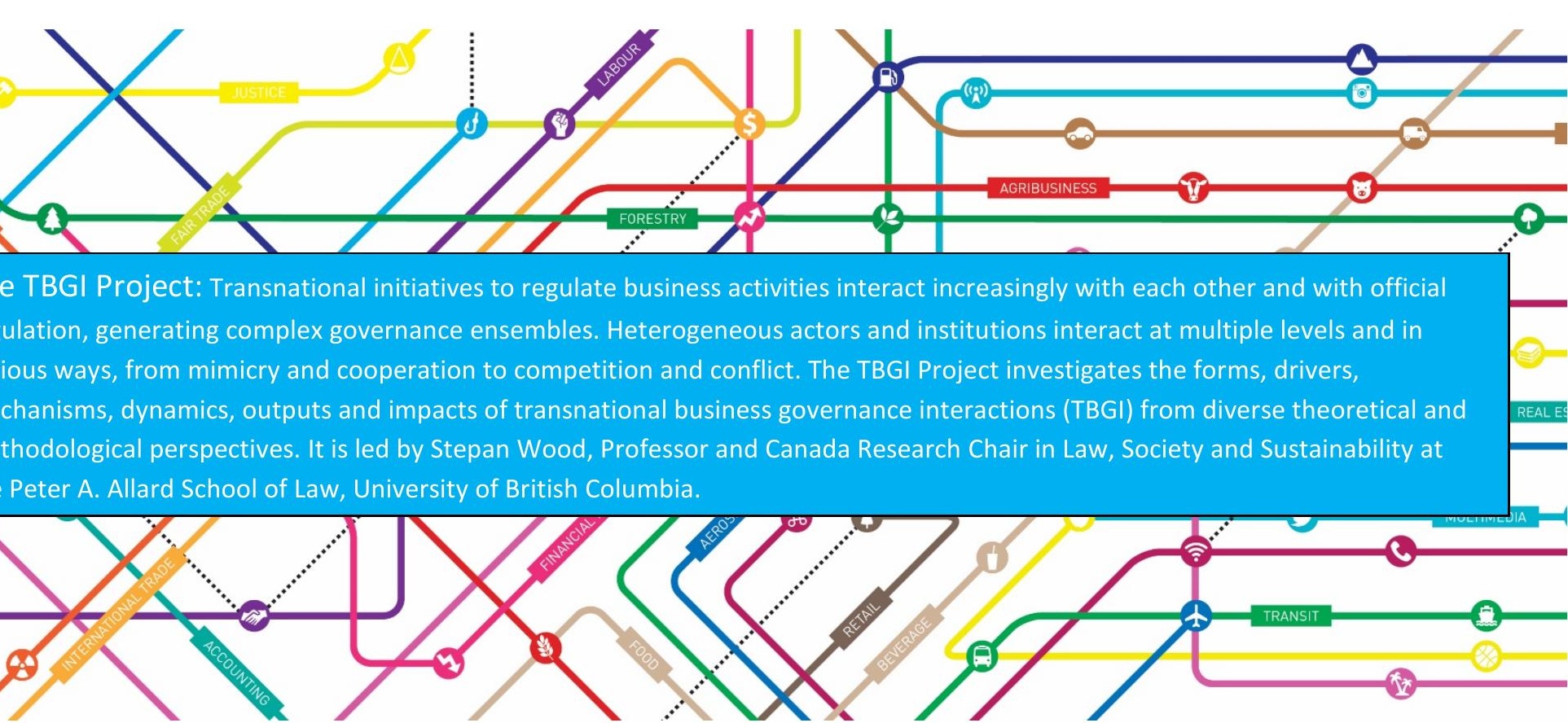




\title{
Interactions, Iteration and Early Institutionalization: Competing Lessons of GLOBALGAP's Legitimation
}

\author{
Donal Casey ${ }^{1}$
}

\begin{abstract}
Since its inception, GLOBALGAP has transformed from an informal grouping of retailers into a highly elaborate regulatory organisation. This chapter critically examines GLOBALGAP's development. I argue that, through an iterative process of legitimation, actual and anticipated interactions with state, market and civil society actors led GLOBALGAP to develop structures, practices and processes that sought to enhance representation and participation of structurally weaker parties such as smallholders, whilst also addressing concerns relating to the exclusionary effect of its standards. I tease out how, as non-state regulatory organisations emerge and develop, they respond to actual and anticipated governance interactions in order to build, maintain and repair their legitimacy. Crucially however, early institutionalisation confers power upon particular actors, crystallises an organisation's identify and lays the foundations for the achievement of its goals. Consequently, the enduring nature of early this institutionalisation can temper the potential for governance interactions to advance democracy, justice and fairness within non-state regulatory organisations.
\end{abstract}

\section{Keywords}

Food Regulation, legitimacy, transnational regulation, private regulation, GLOBALGAP

\section{Introduction}

As non-state regulatory organizations emerge and develop, they respond to anticipated and actual governance interactions to build, maintain and repair their legitimacy. These interactions span not just cooperation, enrolment and co-option, but also antagonistic interactions characterized by provocation and conflict (Eberlein et al. 2014). This chapter examines the emergence and subsequent development of GLOBALGAP, a retailer-led transnational business governance organization that regulates good agricultural practices (GAP) in the areas of crops, livestock and aquaculture. GLOBALGAP develops GAP standards, oversees a system of implementation based upon third-party certification and benchmarking (Casey 2017). I foreground GLOBALGAP's interactions with market, state and civil society actors and the role that these interactions played in organization's legitimation.

What would eventually become GLOBALGAP began in 1996 as an informal grouping of fresh produce quality managers, technical managers and purchasers from 13 European retailers (Möller 1998a, p. 71). The grouping was driven by three significant changes in the legal landscape of European food retailers. Firstly, at the national and European Union (EU) level, governments shifted regulatory responsibility from the state to food business operators. The United Kingdom's Food Safety Act 1990 was the starting point for this devolved responsibility (Scott 1990). Under this 'benchmark piece of

\footnotetext{
${ }^{1}$ Lecturer in Law, Kent Law School, University of Kent. d.k.casey@kent.ac.uk. A revised version of this paper is forthcoming in Stepan Wood et al., eds. Transnational Business Governance Interactions: Empowering Marginalized Actors and Enhancing Regulatory Quality. Cheltenham, UK: Edward Elgar.
} 
devolutionist legislation', primary responsibility for ensuring the safety of all branded food products and fresh unpacked (unbranded) products rested on the final supplier (Campbell, Lawrence, and Smith 2006, p. 71). Following the BSE crisis, the EU adopted a similar approach (ibid). Regulation 178/2002 placed the primary responsibility for ensuring compliance with food law, particularly in relation to food safety, upon food business operators. Secondly, EU product liability rules were extended in the wake of the BSE crisis to include primary agricultural products. Finally, the EU reduced Maximum Residue Levels (MRLS) for pesticides. These changes created risks and incentives that drove the development of new forms of regulation of food safety and quality.

The 13 retailers called themselves the Euro-Retailers Produce Working Group (EUREP) and established a formal membership model to finance the group (Hofmans 1999, p. 6). EUREP described itself as a 'technical working party aimed at promoting and encouraging best agricultural practice in the fruit and vegetable production industry' (Garbutt 1999, p. 5). Over the next years, EUREP engaged in a process of enrolment and sought to expand its membership (Bell and Shelman 2009, p. 3). In 2007, EUREPGAP re-branded itself GLOBALGAP (GLOBALGAP 2007). By the end of 2015, GLOBALGAP's membership had expended to 47 retailer members, 190 producer and supplier members, 153 associate members, and over 150,000 certified producers worldwide.

In this chapter, I argue that an iterative process of legitimation, interactions and the anticipation of interactions with state, market and civil society actors led GLOBALGAP to enhance the representation and participation of structurally weaker parties such as smallholders, and to address concerns about the exclusionary effects of its standards. State, market and civil society actors sought to shift GLOBALGAP towards accommodating both a 'logic of control' and a 'logic of empowerment' (Auld, Renckens, and Cashore 2015). A logic of control places transnational business governance organizations on a path that prioritizes the integrity of the regulatory system and the creation of mechanisms that effectively regulate behaviour and ensure compliance. A logic of empowerment, by contrast, prioritizes the participation in governance organizations of actors that are marginalized in supply chains. However, early institutionalization can confer power upon particular stakeholders and crystallize a dominant logic (ibid). I contend that the enduring nature of early institutionalization shaped GLOBALGAP's responses to legitimacy demands from state, market and civil society actors, and in so doing, tempered the potential for these governance interactions to advance democracy, justice and fairness within the organization.

The chapter proceeds in four parts. Section 2 presents the theoretical framework. Section 3 outlines the ways in which GLOBALGAP managed its legitimacy in its early years by anticipating legitimacy demands and learning from past experience. Section 4 examines how the structures, practices and processes developed in its early years were challenged as GLOBALGAP expanded, and its interactions with state, market and civil society organizations increased. Finally, Section 5 draws attention to the enduring nature of the structures, practices and processes that GLOBALGAP developed in its early years, and how early institutionalization can temper the inherently iterative nature of legitimacy management.

\section{Legitimacy and Legitimation}

Legitimacy has been long recognised as 'an important resource that organizations need to actively gain and maintain through interaction with their environment to be successful' (Richardson and Eberlein 2011, p. 221). As such, legitimacy is one of the main drivers for transnational business governance interactions and the conferral of legitimacy is one of the key effects of such interactions (Eberlein et al. 2014). In what follows, I outline my understanding of GLOBALGAP's legitimation and the role that governance interactions play in this process (Casey 2017).

\subsection{Embedded Regulators}

The key to understanding the legitimating dynamics of non-state regulatory organizations lies in the recognition of their embeddedness in an environment, which constrains and empowers the adoption of particular structures, practices and processes. The notion of embeddedness rests upon a 
theoretical shift in the study of organizations from a closed, rational approach to an open systems model (Meyer 2008, p. 453). While a closed systems perspective viewed organizations as hermetically sealed from their environment, open systems approaches focus our attention on organizations interaction with, and interdependency on their environments (Scott 1998, pp. 112-7). Scholars have carried forward these insights in an attempt to understand the actions and interactions of transnational business governance organizations. Transnational business governance schemes, Doorey explains, 'are a function of developments in the broader social environment' as the social forces within an organisation's environment shape its 'interactions, strategies and outputs' (2015, p. 464). Further, as Bernstein argues, 'what constitutes legitimacy results from the interaction of the community of actors affected by the regulatory institution ... with the broader institutionalized norms ... that prevail in the relevant issue area' (2011, p. 19). As such, legitimacy demands stem from pressures by the stakeholders and the rules, norms and cognitions that occupy the environment within which non-state regulators are embedded.

The legitimacy of transnational business governance organizations is rooted in the evaluations and assessments of their sources of legitimacy - their legitimacy communities (Black 2008, p. 144). The acceptance and legitimacy of a regulator flows from congruence between a regulator's structures, practices, processes and outputs and its legitimacy communities' 'beliefs or expectations or ... interests' (ibid). As Gulbrandsen emphasizes, 'a non-state standards organization must obtain legitimate rule making authority and accept answerability to salient constituencies in its organizational field' $(2008$, p. 568). For legitimacy to be granted, therefore, organizations must be cognisant of and responsive to the legitimacy demands of those actors whose behaviour they seek to shape, or from whom they seek support (Tyler 2006, p. 392).

Identifying GLOBALGAP's legitimacy communities starts in the agricultural supply chain. This supply chain 'directs and frames political struggle of the external audience' as, at each of its stages, market actors choose whether or not they are willing to support GLOBALGAP's activities (Cashore 2002, p. 512). Here, we must distinguish between supply-side actors such as producers and demandside actors such as retailers (Cashore, Auld, and Newsom 2004, pp. 23-6). It is also important to recognise actors operating in the verification market, including inspection, certification and accreditation bodies, as important legitimacy communities for GLOBALGAP, as well as other non-state governance organizations such as the Global Food Safety Initiative (GFSI) (Tamm Hallström and Gustafsson 2014).

State actors represent another significant legitimacy community for GLOBALGAP. States have a direct economic interest in the trade of agricultural products, and develop national food safety and quality standards that interact and compete with non-state standards. At the intergovernmental level, the United Nations Conference on Trade and Development (UNCTAD), the Food and Agricultural Organization (FAO) and the United Nations Industrial Development Organization (UNIDO) are three of the most prominent intergovernmental organizations with interests in the regulation of agricultural value chains, particularly in developing countries. The World Trade Organization (WTO), Codex Alimentarius Commission (Codex), the World Organization for Animal Health (OIE) and the International Plant Protection Convention (IPPC) are also significant. The latter three organizations develop international standards that interact and compete with GLOBALGAP standards, making these organizations a potential source of legitimacy for GLOBALGAP at the international level.

Civil society actors shape non-state regulatory organizations such as GLOBALGAP through interactions such as enrolment, collaboration, provocation and conflict (Bartley 2007, p. 310). Civil society actors include campaign-based non-governmental organizations (NGOs) such as Greenpeace, OXFAM, Friends of the Earth, and the Pesticide Action Network. Other civil society actors are certification-based NGOs, such as the World Wildlife Fund (WWF) and the meta-regulator the ISEAL Alliance and its members. Finally, civil society actors may also take the form of representative organizations such as Bureau Européen des Unions de Consommateurs (BEUC).

However, it is necessary to look beyond the demands of legitimacy communities, and examine legitimacy demands that take the form of institutionalized norms that structure the environment in 
which transnational business governance organizations are embedded (Djelic and Sahlin-Anderson 2006b, p. 21). As Wood and colleagues have observed:

Theoretical frameworks ... that analyse strategic action in isolation from the social structures in which it occurs, will fail to grasp all the dynamics of governance interactions (2015, p. 350).

Scholars have begun to explore the social structure norms that constrain and empower contemporary transnational business governance organizations (Djelic and Sahlin-Anderson 2006a, pp. 382-3; Bernstein 2011; Auld 2014; Auld, Renckens, and Cashore 2015). Perhaps the most pertinent of these norms for this chapter is 'democratization'. This normative pressure takes the form of promoting a model of governance that provide structures and procedures that advance transparency, openness, representation, participation, deliberation and consensus.

\subsection{Managing Legitimacy}

Early scholars' suggestions that organizations were passive to the uniform pressures exerted within institutional environments neglected the possibility for organizations to act strategically in their reaction to such pressures, and the role of choice, agency and interests in such actions (Child 1972, p. 4; DiMaggio 1988, pp. 3-22). Given the complexity of environments that impose diverse and potentially conflicting legitimacy demands, seams of latitude emerge (Suchman 1995, pp. 585-6). These seams emerge from the tension created by the inability to integrate all legitimacy demands and the bounded nature of possible action if a regulator is to survive (ibid). Within this setting, organizations 'can and do formulate strategies for fostering legitimating perceptions of desirability, proprietary and appropriateness' (ibid, p. 577). Given the multitude of legitimacy demands and the potential for conflict amongst them, non-state regulatory organizations must decide which sources of legitimacy to respond to (Scott 1987, p. 502).

It has been argued that this decision, which lies at the heart of legitimacy management, is shaped by the actor making legitimacy demands and the content of those demands (Oliver 1991, p. 161). Organizations have central and peripheral legitimacy communities (Suddaby, Cooper, and Greenwood 2007). These legitimacy communities exert different degrees of influence, which can change over time (ibid). A legitimacy community may have influence over an organization for a number of reasons. Regulatory organization may be dependent upon certain actors for important resources such as capital, expertise, endorsements or personnel (Oliver 1991, p. 164). Further, legitimacy communities may be represented within an organization or have the power to determine its response given the organisation's decision-making and membership structure (Pache and Santos 2010, pp. 160-1). Indeed, a regulatory organisation's governance structure acts as a 'filter' for legitimacy demands (Greenwood et al. 2011, pp. 342-6). The content of legitimacy demands and the means by which they are imposed are also significant for understanding organizations' management of legitimacy (Oliver 1991, pp. 167-170). An organization's identity, goals and objectives may temper its response to legitimacy demands as conformance may interfere with the organization's ability to fulfil its core mission or may jar with its identify (Oliver 1991, pp. 164-7; Pache and Santos 2010, pp. 459-460; Greenwood et al. 2011, p. 347). In this context, Auld and colleagues speak about challenges to the particular logic of a transnational business governance organization, and the willingness of organizations such as the Forest Stewardship Council (FSC) to accommodate demands that seek to shift the organization from one logic to another (Auld, Renckens, and Cashore 2015).

Legitimacy is 'always problematic' as social values and expectations are often ambiguous, contradictory and ever evolving (Ashforth and Gibbs 1990, p. 177). What constitutes legitimate structures, practices and processes is not stable and is difficult to anticipate in advance (Boström and Tamm Hallström 2013, p. 102). Non-state regulatory organizations must build, revise and recast themselves in order to manage their legitimacy. While legitimation is inherently iterative, the early institutionalization of structures, practices and processes can have a significant impact on it by cementing the distribution of power within an organization and crystallizing a dominant organizational 
logic (Tamm Hallström and Boström 2010, p. 111). The enduring nature of early institutionalization can thus temper the potential for governance interactions to advance democracy, justice and fairness within non-state regulatory organizations.

\section{Anticipation and Learning}

Those involved in the emergence of non-state regulators cannot know in advance what actors the organization will interact with, or indeed the legitimacy demands that will be made of the organization. GLOBALGAP's management of legitimacy in its early years was anticipatory and relied upon its founders' prior learning and experience. The anticipatory nature of legitimacy management in an organization's infancy is central to the iterative nature of legitimation.

\subsection{Anticipating Demands}

While retailers were the driving force behind GLOBALGAP, the organization sought support from producers and suppliers in 1999 and opened the organization to associate members, including producers, suppliers, certification bodies, agricultural consultancies and other organizations. Through this process of enrolment, associate members could participate in the organization's technical subcommittees and contribute to the development of the GLOBALGAP protocol (Hofmans 1999, p. 6). Although GLOBALGAP had little interaction in its early years with stakeholders beyond the associate membership constituency, it sought to anticipate legitimacy demands from both state and civil society organizations.

An important change in GLOBALGAP's governance occurred in 2000. The organization adopted a three-tier membership structure, which still exists today, comprising retail members (tier 1 ), supplier and producer members (tier 2 ), and other associate members (tier 3 ). It also proposed to create a formal supply-chain partnership of retailers, producers and suppliers (EUREPGAP 2001a). The retailer, producer and supplier members of GLOBALGAP adopted the proposal for a formalized supplychain partnership at a joint meeting in January 2001 (EUREPGAP 2001a). They created a Steering Committee and a Technical and Standards Committee, constituted by retail and supplier members only, as GLOBALGAP's core decision-making bodies (EUREPGAP 2001c, EUREPGAP 2001d). Interestingly, there was also an ambition to establish a broader multi-stakeholder GLOBALGAP Council composed of state and civil society actors, which would have had a consultative role (EUREPGAP 2001b; van der Grijp 2008, p. 127).

The opening up of GLOBALGAP's membership and the establishment of the supply-chain partnership signalled to broader stakeholders that GLOBALGAP had support from the entire supplychain and was not just a retail-led initiative. Furthermore, in expanding its membership, GLOBALGAP anticipated and responded to possible demands of civil society and state actors to legitimate its governance and standard setting (EUREPGAP 2000; Möller 2006, p. 26). A GLOBALGAP representative opined that a governance structure 'involving all supply-chain stakeholders' would lead 'to a high acceptance throughout the sector including Governments and NGOs' (EUREPGAP 2000). The organization also noted that '[a]cceptance by NGOs and Consumer organizations as well as governments and their organizations can be achieved by including them in the advising and standard setting structures' (EUREPGAP 2001e, p. 16).

The anticipatory nature of GLOBALGAP's legitimation extended beyond its governance and standard setting and to the organization's system of implementation. An interviewee pointed out that third-party certification was not commonly used to implement food safety and quality standards when GLOBALGAP was established. The development of the organization's system of implementation based upon accredited third-party certification was a response to demands from accreditation bodies, but also an attempt to gain acceptance from civil society, state and market actors by anticipating a variety of potential legitimacy demands from these stakeholders (Casey 2017). In 2000, following recommendations from accreditation bodies, the retail membership of GLOBALGAP decided that third-party certification would be required for all grower options (Möller 2000; Casey 2017). Once the implementation system based upon accreditation to ISO Guide 65 was established, the chairperson of 
GLOBALGAP's Technical and Standards Committee emphasized that '[t]he key to all stakeholder and government recognition of ... schemes is an ISO accreditation' (EUREPGAP 2001e, p. 16). Furthermore, a GLOBALGAP representative observed that accredited third-party certification would 'also help guarantee transparency towards media and challenges from non-governmental organisations' (Garbutt and Möller 1999, p. 32). Thus, GLOBALGAP anticipated that accredited third-party certification would provide broad acceptance from state and civil society actors, along with the support the organization received from market actors.

\subsection{Learning and Past Experience}

The establishment of the supply-chain partnership and a system of implementation based upon accredited third-party certification were responses to actual legitimacy demands from market actors and anticipated demands from state and civil society actors. However, the prior learning and experience of the GLOBALGAP's founders heavily influenced the organization's legitimation and responses to these demands. As Schleifer notes, '[i]nstitutional entrepreneurs and their choices are often informed by the lessons they draw from their experiences and the experiences of others' (2015, pp. 6-7).

GLOBALGAP's founders drew upon their prior experience and learning from other regulatory organizations in their attempt to legitimate GLOBALGAP's governance and standard setting. The understanding of the importance of producer and supplier participation was gained through previous experience in establishing a beef labelling scheme in Germany (Wise 1998, p. 96; Möller 1998b). The idea of industry control of key decision-making bodies along with a broader stakeholder consultative council was also a consequence of prior learning. A number of GLOBALGAP's founding members had been part of the UK's Assured Produce Scheme. Inspiration for the supply-chain partnership model appears to have come from GLOBALGAP's initial study of the Assured Produce Scheme's partnership between the National Farmers Union and retailers (ibid). Furthermore, the Marine Stewardship Council (MSC) developed a similar consultative body in July 2001 (Gulbrandsen 2008, pp. 571-2). As such, the supply-chain partnership and the proposed GLOBALGAP Council can be seen as conscious mimicry of existing institutional models and conformance with the institutional force of democratization.

Prior learning influenced not only standard setting and governance but also GLOBALGAP's approach to the implementation of its standards. Reflecting upon the experience of the Assured Produce Scheme, a GLOBALGAP report noted that:

[A]n independent verification system is an essential part of any credible and transparent assurance scheme. Experience shows that consumers and opinion formers place little reliance on self-regulation (Wise 1998, p. 96).

Thus, GLOBALGAP's move to accredited third-party certification was a response to anticipated legitimacy demands. Importantly, however, GLOBALGAP's response was, in large part, informed by the experience and lessons learned by its founders.

GLOBALGAP had very little interaction with state and civil society actors in its early years and remained largely under their radar as it emerged (EUREP 1999). During this period, GLOBALGAP focused on enrolling market actors such as retailers, producers and suppliers, as well as certification and inspection bodies. Nevertheless, it is striking the extent to which GLOBALGAP sought to anticipate the legitimacy demands of state and civil society actors, and the degree to which its legitimacy management was informed by prior learning and experience. However, non-state regulatory organizations cannot know in advance exactly whom they will interact with, or what demands stakeholders will make of them. Indeed, 'legitimacy cannot be a stable condition but is something fluid that must be repeatedly created, recreated, and conquered' (Boström and Tamm Hallström 2013, p. 102). 


\section{Interactions and Responses}

Managing legitimacy becomes particularly problematic as non-state regulatory organizations expand in scope, scale and complexity, and are subjected to conflicting demands from an increasing number of legitimacy communities (Ashforth and Gibbs 1990, p. 177). This section examines GLOBALGAP's inability to fully anticipate and satisfy the legitimacy demands of market, state and civil society actors as the governance, standard setting and implementation systems initially developed. In response, GLOBALGAP iteratively rebuilt, revised and strengthened its governance, standard setting and implementation activities into order to manage its legitimacy.

\subsection{Increased Interaction and Demands}

The years following 2001 saw increased criticisms of GLOBALGAP's governance and standard setting by market, state and civil society actors. Producers and suppliers challenged the extent to which the supply-chain partnership gave them sufficient influence and voice within the organization (Leighton 2002; 2003; 2006). Civil society and state actors demanded that GLOBALGAP open up to wider stakeholder representation. For example, during the 2001 GLOBALGAP conference in Bologna an FAO representative stressed that GLOBALGAP must 'undertake greater consultation with stakeholders to ensure that it responds to diversity' (Tallontire et al. 2008, p. 15). State actors also requested direct consumer representation within the organization (EUREPGAP 2003, p. 4). UNCTAD and the European Commission called for wider stakeholder involvement in GLOBALGAP's governance to ensure representation of all stakeholders' views and interests (Hoffmann and Vossenaar 2007, p. 19; Interview). In 2002, the European Commission observed that GLOBALGAP did not have an open, public and documented consultation process, and that there were limited mechanisms for participation of interested parties (European Commission 2002). The report concluded that GLOBALGAP failed to meet the participation requirements found in ISO standard-setting guidelines. Civil society actors also demanded that GLOBALGAP provide stakeholder participation beyond market actors within its governance and standard setting, and expressed concerns about the organization's openness and transparency. Indeed, an interviewee stressed that NGOs shared the concern for multi stakeholder participation and transparency within non-state regulators' governance and standard setting (see also Greenpeace 2010, p. 3).

One of the more prominent criticisms of GLOBALGAP has been the limited participation of smallholders within its governance and standard setting (Interview). An interviewee explained that the German semi-state development agency Deutsche Gesellschaft für Technische Zusammenarbeit (GTZ) requested that GLOBALGAP 'open up some representation space' for small holders within its governance structure. Further, UNCTAD reported in 2006 that GLOBALGAP standards did not 'adequately take into account local conditions of developing countries' and that there was 'a need for more dialogue between representatives of private-sector standard-setting organizations, governments and producers/exporters in developing countries' (Hoffmann and Vossenaar 2007, p. 18).

Concerns about participation in and transparency of GLOBALGAP's standard setting procedure were voiced loudly within the WTO Committee on Sanitary and Phytosanitary Measures (SPS Committee). The Chairperson of GLOBALGAP, Nigel Garbutt, attended a side event during the 2007 WTO SPS Committee meeting (World Trade Organization 2007b). During the main meeting, St. Vincent and the Grenadines, the Bahamas and Egypt called for non-state standard setting organizations such as GLOBALGAP to 'ensure the involvement of producers in developing the standards' (ibid, p. 10). Further, state actors argued that 'proliferation of private standards' raised concerns about the lack of transparency in the manner that the standards are set (ibid, p. 10). An Interviewee noted that the concerns raised within the SPS Committee had a significant influence on how GLOBALGAP responded to concerns relating to the participation of smallholders within its governance and standard setting.

GLOBALGAP's system of implementation was also the subject of criticism. While stakeholders recognised the cost of implementation borne by producers as an issue, this issue became increasingly vocalized as GLOBALGAP expanded. Producers, state and civil society actors communicated concern to GLOBALGAP about the cost of implementation and the exclusionary impact of these costs on 
producers in both developed and developing countries (see for example COLEACP/PIP, p. 2; World Trade Organization 2007a, p. 4; UNCTAD 2005; World Trade Organization 2005; World Trade Organization 2006b, p. 11; World Trade Organization 2006a; Freshfel 2006). An interviewee explained that, like many states, civil society actors viewed the cost implications for producers negatively and had communicated these concerns to GLOBALGAP. The interviewee stressed that GLOBALGAP's certification practices meant that 'there was no element of equity at the bottom of the value chain', and that there was 'nothing in the structural arrangements of GLOBALGAP to deal with such inequity in relation to the cost of compliance'.

\subsection{Continued Learning and Responding to Legitimacy Demands}

In developing certain standards, GLOBALGAP engaged in a process of co-option, cooperation and enrolment of actors within the standard setting process. For example, to develop the GLOBALGAP Risk Assessment on Social Practices standard (GRASP, a voluntary add-on module that assesses the social practices in the primary production process), GLOBALGAP and the retailer COOP sought cooperation through a public/private partnership with GTZ between June 2005 and April 2007 (Heise, Uhlig, and Vonwiller 2007). In developing the shrimp base of its aquaculture standard, GLOBALGAP directly engaged with the NGOs Oxfam/Novib and the International Union for Conservation of Nature (IUCN) (Interview; van Mulekom and Parr 2007). The standard setting process for both the GRASP addon module and the aquaculture shrimp standard provided not just broader consultation than previous GLOBALGAP standards, but also introduced novel participatory mechanisms such as stakeholder workshops (Heise, Uhlig, and Vonwiller 2007; Garbutt 2008). Tallontire et al note that '[t]he aquaculture standard development process ... appear[ed] to mark a significant change in stakeholder engagement, demonstrating a new openness' $(2008, p$. 17). The learning that took place in the development of these standards, and through GLOBALGAP's cooperative interactions with state and civil society actors such as GTZ and Oxfam/Novib, carried forward into GLOBALGAP's general approach to standard setting and its response to the concerns relating thereto.

The 2006 GLOBALGAP conference in Prague, which was part of a standard revision process ending in 2007, sought to provide not only greater transparency about the revision process, but also more space for participation in it (EUREPGAP 2006). UNCTAD noted that the 2007 revision process was 'an indicator of progress' towards greater transparency and participation (World Trade Organization 2007a, p. 9). By the end of 2006, GLOBALGAP also began to draw upon the transparency and participation requirements contained in international standards to legitimate its standard revision process and respond to increasing concerns raised by market, state and civil society actors (Casey 2017).

In 2011, GLOBALGAP began to introduce new Stakeholder Committees to formalize wider stakeholder participation in its governance structures. An interviewee noted that, due to the limited success of previous efforts to integrate wider stakeholder participation within the organization, a more focused attempt was employed to target specific stakeholder groups. Membership of the Stakeholder Committees consisted of individuals from retail, producer, supplier, certification body, research, NGO, governmental, standard setting, consultant and information technology organizations (GLOBALGAP 2012). The Stakeholder Committees have since been transformed into focus groups. The establishment of the Stakeholder Committees and focus groups suggests GLOBALGAP's continued perception of the importance of wider stakeholder participation within its governance for the acceptance of the organization by certain market, state and civil society actors.

From 2007, GLOBALGAP responded to the increasing criticisms of the closed nature of the supply-chain partnership by acknowledging 'that there are particular issues to be considered with regard to smallholders, especially those in Africa and other parts of the developing world' (Tallontire et al. 2008, p. 15). The creation of an African Observer and a Smallholder Taskforce in 2007 and 2008, respectively, sought to integrate smallholders within GLOBALGAP's governance and standard setting. These initiatives, developed in cooperation with GTZ and the UK Department for International Development (DFID), were designed to represent African smallholders at both Sector Committee and Board level (African Observer 2007; GLOBALGAP 2007). 
The African Observer project and many of the developments discussed previously are part of a trend to open GLOBALGAP to wider participation and consultation (Tallontire, Opondo, and Nelson 2013 , p. 8). Transnational business governance organizations 'have to adjust and evolve to meet changing and growing expectations around their democratic and inclusive character' (Auld, Renckens, and Cashore 2015, p. 118). Wood and colleagues prompt us to look beyond interactions with actors to incorporate interactions with structural features such as norms and discourses (2015, p. 350). In understanding this move towards the opening up of GLOBALGAP, we must also pay attention to the important role that that dominant discourse of democratization plays in this process (Djelic and SahlinAnderson 2006a, pp. 382-3).

GLOBALGAP also responded to key legitimacy demands in relation to its system of implementation. It recognized the cost of implementation as an important issue at an early stage and introduced the option of group certification as a means to reduce the costs for smallholders (Hofmans and Garbutt 2001, Supplement, p. 3). Between 2004 and 2006, GLOBALGAP cooperated with UNCTAD in a project aimed at understanding how smallholders in developing countries could comply with food safety standards and gain access to export markets (Garbutt and Coetzer 2005). In so doing, GLOBALGAP representatives focused their attention on the ability of national producer organizations and states to benchmark national GAP schemes against the GLOBALGAP standard. GLOBALGAP also cooperated with GTZ to develop a GLOBALGAP Smallholder Manual and engaged in stakeholder consultation in relation to the development of a more effective means of group certification (EUREPGAP 2005, p. 40; Tallontire et al. 2008, p, 17; GTZ 2010; African Observer 2008).

GLOBALGAP built, revised and recast itself in an iterative, trial-and-error manner in order to manage its legitimacy. The anticipatory nature of legitimacy management in a non-state regulatory organization's early years can lead to structures that do not meet the later expectations of the organization's legitimacy communities. Further, as non-state regulatory organizations expand, they attract new legitimacy communities whose demands may conflict with the organization's extant structures, practices and processes. As GLOBALGAP's legitimacy communities expanded beyond market actors such as large retailers and producers with key concerns relating to food safety, to include both state and civil society actors, the demands made against GLOBALGAP moved beyond food safety to concerns relating to the marginalization of smaller producers and the inclusiveness of its governance and standard setting.

\section{Early Institutionalization}

The structures, practices and processes established during a non-state regulatory organization's early years have an enduring quality (Tamm Hallström and Boström 2010, p. 111). As Auld observes, 'early design choices can generate hard-to-overcome inertia shaping subsequent developments' (2014, p. 17). Indeed, 'depending on their starting points', transnational business governance organizations such as the FSC and MSC have responded to legitimacy demands 'in different ways and with varying effects on actors' regulatory capabilities and the distribution of power' (Auld, Renckens, and Cashore 2015, p. 118). GLOBALGAP's early institutionalization conferred power upon particular legitimacy communities and crystallized a dominant logic within an organization. As such, early institutionalization is crucial for our understanding of how and why GLOBALGAP has managed its legitimacy in the way it has.

\subsection{Institutionalization of Power, Internal Cohesion and Shared Commitment}

Membership categories both confer and withhold powers from particular actors. GLOBALGAP's adoption of the supply-chain partnership and three-tiered membership structure (retailer, supplier/producer and associate) can be seen as both a process of inclusion and exclusion, with implications for the power and roles of particular actors within the organization (Tamm Hallström and Boström 2010, Chapter 8). It solidified power within particular constituencies, namely retailers, suppliers and large producers. 
Further, the institutionalization of the supply-chain partnership positioned GLOBALGAP as an industry-led organization, and provided internal cohesion and commitment within the organization. The central legitimacy communities of the supply-chain partnership were industry actors that shared reputational and legal risks and prioritized a logic of control within the organization.

In managing its legitimacy, GLOBALGAP strongly resisted attempts to undermine the supplychain partnership at its core and left intact the three-tiered membership structure and the resulting allocation of power to market actors. In GLOBALGAP's early years, retailers, producers and suppliers kept power within the Steering Committee and the Technical and Standards Committee, and proposed to give a weaker consultative role to the Council as a multi-stakeholder body (Tamm Hallström and Boström 2010, p. 148). While the development of the Stakeholder Committees more recently within the organization represented a trend towards the democratization of GLOBALGAP, they did not undermine the supply-chain partnership's power in the organization's core decision-making bodies. Indeed, the Stakeholder Committees' terms of reference stated that '[t]he relationship to NGOs should remain unchanged' (GLOBALGAP 2012). In addition, although GLOBALGAP's standard setting procedure evolved to enhance transparency, openness and participation, the role of the Sector Committees and the supply-chain partnership in setting standards was not undermined. Rather, the formalized standard-setting procedure was superimposed upon the existing supply-chain partnership model of standard setting.

As such, supply-chain actors defended challenges to their power in GLOBALGAP's key decision making bodies (Interview; Bell and Shelman 2009, p. 9). Wider stakeholder involvement was seen as a challenge not only to the existing distribution of power within the organization, but also to the internal cohesion and commitment that had been built up at the organization's core, which was founded upon the shared reputational and legal risks of GLOBALGAP's central legitimacy communities represented in the supply-chain partnership. One interviewee explained that:

[T] he industry feels that they need to have the responsibility where it belongs. When they have financial and legal accountability, they would like to take the decisions, and that means that when we talk about whether we have NGOs, civil society or government organizations in our decision making roles? No.

Indeed, a civil society representative emphasized that any discussion of broader multi-stakeholder participation within GLOBALGAP's governance was a no-go area'. As Auld and colleagues note in their discussion of the FSC, MSC and Fairtrade International (FLO), '[t] he participation of more stakeholders with varying interests can threaten internal cohesion and established positions of internal dominance' (2015, p. 119).

The institutionalization of the supply-chain partnership at its core framed GLOBALGAP's response to demands to embed wider stakeholder participation within its governance structure. GLOBALGAP has largely resisted legitimacy demands targeted at the power vested in the supply-chain partnership, which are seen to challenge not only the current balance of power within the key-decision making bodies, but also the internal cohesion and shared commitment that the supply-chain partnership provided. The emergence of GLOBALGAP as a retailer-led initiative and the subsequent establishment of the supply-chain partnership crystallized the identity of GLOBALGAP as an industryled regulatory organization. The creation of three membership categories made a clear statement regarding which actors constituted the core and which the periphery of the organization. This distinction is reflected in GLOBALGAP's key decision-making bodies.

\subsection{Protecting the Logic of Control}

Early institutionalization not only confers powers upon particular legitimacy communities, it also lays the foundations for the achievement of the organization's goals and objectives. Reflecting a logic of control, one of GLOBALGAP's founding objectives is a regulatory system based upon a single robust standard implemented through third-party verification. 
While GLOBALGAP representatives recognized that the standard's stringency and third-party certification costs lie at the heart of critics' concerns, they have dismissed demands that would undermine the core objectives of the organization and its dominant logic of control institutionalized in its early years. As I noted above, GLOBALGAP responded to the increased criticisms in relation to the cost of implementation for smallholders in a number of ways. Firstly, it continued its cooperation with GTZ to develop a smallholder manual to facilitate the implementation of the standard (GTZ 2010). Secondly, it engaged in stakeholder consultation in relation to the development of a more effective means of group certification (African Observer 2008). While these responses sought to accommodate and address concerns relating to the cost of implementation, they did so in a manner that did not undermine either GLOBALGAP's standard or third-party certification, which are two of the core features that underpin the organization's initial and dominant logic of control.

A GLOBALGAP representative stressed that 'the value of the reference standard is that it's the same for everybody' and that GLOBALGAP's 'position is obviously that "the standard is the standard" and that it wouldn't be appropriate to have one standard for one part of the world and a standard for another' (PIP/COLEACP 2004, p. 4). In addition, the representative highlighted that the cost of certification is determined by the market, and that in 'a competitive market for certification' it is up to producers to negotiate and 'shop around' (ibid). In GLOBALGAP's strategic manoeuvring around the concerns from state, market and civil society actors in relation to the cost of implementation, we can observe the importance of a non-state regulator's goals and dominant logic in determining how they manage legitimacy demands (Oliver 1991, pp. 164-7; Pache and Santos 2010, pp. 459-460).

\section{Conclusion}

GLOBALGAP's structures and processes became increasingly complex as it managed its legitimacy and responded to legitimacy demands. Indeed, non-state regulatory organizations expand 'in all directions: centrally, de-centrally, and horizontally' as they seek to manage their legitimacy (Tamm Hallström and Boström 2010, p. 167). The complexity of a non-state regulatory organization in turn reflects the power and underlying logic of that organization.

Legitimation is an inherently iterative process that drives and shapes transnational business governance interactions. A striking feature of GLOBALGAP's management of legitimacy during its early years is how the organization sought to anticipate the legitimacy demands of state and civil society actors and to legitimate itself based upon what the actors involved in the organization at that stage had learned from previous experience. GLOBALGAP's inability to anticipate fully and accurately civil society and state actors' legitimacy demands, and to ensure that its responses satisfied the demands of market actors, shines through in the discussions above. In responding to these criticisms, GLOBALGAP had to engage in the iterative processes of rebuilding, revising and strengthening its governance, standard setting and implementation activities in order to gain, maintain and repair its legitimacy.

Through this iterative process of legitimation, interactions and the anticipation of interactions with state, market and civil society actors led GLOBALGAP to enhance the representation and participation of structurally weaker parties within the organization and address concerns relating to the exclusionary effects of its standards. However, early institutionalization of an organization's structures, practices and processes has a significant impact upon how they manage their legitimacy. As I argued above, the enduring nature of early institutionalization shaped how GLOBALGAP responded to legitimacy demands from state, market and civil society actors. Significantly, early institutionalization tempered the potential for governance interactions to advance democracy, justice and fairness within the organization. 


\section{References}

African Observer. 2007. African Observer: About Us. Internet Archive 20 August 2008, http://web.archive.org/web/20080820231944/http://www.africa-observer.info/about.html.

African Observer. 2008. GLOBALGAP Group Certification: A Challenge for Smallholders in Europe and Developing Countries 28-29 April 2008: Workshop Report. Internet Archive 20 August 2008, http://web.archive.org/web/20080820231934/http://www.africaobserver.info/documents/Report_GLOBALGAP_workshop.pdf.

Ashforth, Blake E, and Barrie W Gibbs. 1990. The Double Edge Sword of Organizational Legitimation. Organizational Science 1 (2):177-194.

Auld, Graeme. 2014. Constructing Private Governance: The Rise and Evolution of Forest, Coffee, and Fisheries Certification. New Haven and London: Yale University Press.

Auld, Graeme, Stefan Renckens, and Benjamin Cashore. 2015. Transnational Private Governance between the Logics of Empowerment and Control. Regulation \& Governance 9 (2):108-124.

Bartley, Tim. 2007. Institutional Emergence in an Era of Globalization: The Rise of Transnational Private Regulation of Labour and Environmental Conditions. American Journal of Sociology 113 (2):297-351.

Bell, David E, and Mary Shelman. 2009. GLOBALGAP: Food Safety and Private Standards. In Harvard Business School Case Study 9-509-004: Harvard Business School.

Bernstein, Steven. 2011. Legitimacy in Intergovernmental and Non-State Global Governance. Review of International Political Economy 18 (1):17-51.

Black, Julia. 2008. Constructing and Contesting Legitimacy and Accountability in Polycentric Regulatory Regimes. Regulation \& Governance 2 (2):137-164.

Boström, Magnus, and Kristina Tamm Hallström. 2013. Global Multi-Stakeholder Standard Setters: How Fragile are They? Journal of Global Ethics 9 (1):93-110.

Campbell, Hugh, Geoffrey Lawrence, and Kiah Smith. 2006. Audit Culture and the Antipodes: The Implications of EurepGAP for New Zealand and Australian Agri-Food Industries. In Between the Local and the Global: Confronting Complexity in the Contemporary Agri-Food Sector, edited by T. Marsden and J. Murdoch: Elsevier JAI.

Casey, Donal. 2017. Structuring Private Food Safety Governance. GLOBALGAP and the Legitimating Role of the State and Rule Intermediaries. In Hybridization of Food Governance: Trends, Types and Results, edited by P. Verbruggan and T. Havinga.

Cashore, Benjamin. 2002. Legitimacy and the Privatization of Environmental Governance: How NonState Market-Driven (NSMD) Governance Systems Gain Rule-Making Authority. Governance: An International Journal of Policy, Administration and Institutions 15 (4):503-529.

Cashore, Benjamin, Graeme Auld, and Deanna Newsom. 2004. Governing Through Markets: Forest Certification and the Emergence of Non-State Authority: Yale University Press.

Child, John. 1972. Organizational Structure, environment and performance: The Role of Strategic Choice. Sociology 6 (1):1-22.

COLEACP/PIP. Eurep-Gap Confernece: PIP Details the Hardship of ACOP Exporters. (2003) 2 PIP Magazine: Magazine of the Pesticides Initiative Programmes, http://www.coleacp.org/system/files/file/pip_mag_en/02.pdf.

DiMaggio, Paul J. 1988. Interest and Agency in Institutional Theory. In Institutional Patterns and Organizations: Culture and Environment, edited by L. G. Zucker: Ballinger Publishing Co.

Djelic, Marie-Laure, and Kerstin Sahlin-Anderson. 2006a. Institutional Dynamics in an Re-Ordering World. In Transnational Governance: Institutional Dynamics of Regulation, edited by M.-L. Djelic and K. Sahlin-Anderson: Cambridge University Press.

Djelic, Marie-Laure, and Kerstin Sahlin-Anderson. 2006b. Introduction: A World of Governance: The Rise of Transnational Regulation. In Transnational Governance: Institutional Dynamics of Regulation, edited by M.-L. Djelic and K. Sahlin-Anderson: Cambridge University Press.

Doorey, David J. 2015. Mapping the ascendance of the 'living wage' standard in non-state global labour codes. Transnational Legal Theory 6(2): 435-465 
Eberlein, Burkard, Kenneth W Abbott, Julia Black, Errol Meidinger, and Stepan Wood. 2014. Transnational Business Governance Interactions: Conceptualization and Framework for Analysis. Regulation \& Governance 8 (1):1-21.

EUREP. 1999. EUREPGAP Verification 2000 Official Launch Conference: List of Represented Countries and Companies. Internet Archive 12 February 2001, http://web.archive.org/web/20010212101438/http://www.eurep.org/arbeitskreise/seiten/ eurep-ak-eurep-Part_Org.htm.

EUREPGAP. 2000. EUREPGAP Implementation 2000 Plus Conference: Supplement. In EUREPGAP Implementation 2000 Plus, edited by K. Möller: EHI EuroHandelsinstitut Gmbh.

EUREPGAP. 2001a. 1st EUREPGAP/FOODPLUS Steering Committee Meeting. Internet Archive 23 June 2001, http://web.archive.org/web/20010623150547/http://www.eurep.org/arbeitskreise/seiten/ news-sc-meeting_5-4-01.htm.

EUREPGAP. 2001b. EUREPGAP Council: Statutes, Members and Decisions. Internet Archive 6 March 2002, http://web.archive.org/web/20021220143950/http://www.eurep.org/sites/Councilmembers.html.

EUREPGAP. 2001c. EUREPGAP/FoodPLUS GmbH Steering Committee Terms of Reference. Internet Archive 6 November 2001, http://web.archive.org/web/20031018002318/http://www.eurep.org/downloads/SCTERMS-of-Reference-5-4-01.pdf.

EUREPGAP. 2001d. Terms of Reference for EUREPGAP Technical and Standards Committee: Fruit and Vegetables: FoodPLUS GmbH.

EUREPGAP. 2001e. Understanding EUREPGAP Certification. In EUREPGAP: The Global Partnership for Safe and Sustainable Agriculture - Partnership 2001 Plus, edited by N. Garbutt: EUREPGAP c/o FoodPLUS GmbH.

EUREPGAP. 2003. EUREPGAP News Update June 2003. EUREPGAP c/o FoodPLUS GmbH.

EUREPGAP. 2005. EUREPGAP Global Report 2005. (FoodPLUS GbmH, 2005), www2.globalgap.org/documents/webdocs/E-book-Globalreport.pdf.

EUREPGAP. 2006. Prague Conference Report September 2006. http://www2.globalgap.org/documents/webdocs/EurepGAP_Newsletter_Allscopes_web.pdf.

European Commission. 2002. Evaluation of Environmental Product Declaration Schemes: Final Report. DG Environment.

Freshfel. 2006. Suppliers Statement at the EurepGAP Conference: 21 September - Prague. http://www.forumphyto.fr/wp-content/uploads/2011/07/060921EGStatementEng.pdf.

Garbutt, Nigel. 1999. Why EUREP? In EUREPGAP Verification 2000, edited by K. Möller: EHI EuroHandelsinstitut Gmbh.

Garbutt, Nigel. 2008. GLOBALGAP Aqua Culture Certification. Presentation at FAO/NACA/SCA/DFID Expert Workshop on Guidelines for Aquaculture Certification London, UK 28-29 February 2008, http://library.enaca.org/certification/london08/05_globalgap.pdf.

Garbutt, Nigel, and Elmé Coetzer. 2005. Options for the Development of National/Sub-regional Codes of Good Agricultural Practice for Horticultural Products Benchmarked to EurepGAP: Consultation Draft. (Study Prepared for UNCTAD, 2005), http://rO.unctad.org/trade_env/test1/meetings/inmetro2/EurepGAP_benchmarking_UNCTA D_November-NG.pdf.

Garbutt, Nigel, and Kristian Möller. 1999. Pathway to Independent Verification. In EUREPGAP Verification 2000, edited by K. Möller: EHI EuroHandelsinstitut Gmbh.

GLOBALGAP. 2007a. Press Release: EUREPGAP now GLOBALGAP. http://www.GLOBALGAP.org/cms/upload/Documents/070907_press_release_GLOBALGAP_ ENG-KM.pdf. 
GLOBALGAP. 2007b. Smallholder Task Force: Background and Objective. Internet Archive 5 July 2010, http://web.archive.org/web/20100705042612/http://www.globalgap.org/cms/upload/Abou t_Us/Smallholder-Involvement/Smallholder-Taskforce-Members.pdf.

GLOBALGAP. 2012. GLOBALGAP Stakeholder Committees. http://www.globalgap.org/cms/front_content.php?idcat=17.

Greenpeace. 2010. Greenpeace Briefing: Assessment of the GLOBALGAP Aquaculture Certification Programme.

http://www.greenpeace.org/international/PageFiles/42959/GlobalGap\%20assessment\%20b riefing\%2OFINAL.pdf.

Greenwood, Royston, Mia Raynard, Farah Kodeih, Evelyn R Micelotta, and Michael Lounsbury. 2011. Institutional Complexity and Organizational Responses. The Academy of Management Annals 5 (1):317-371.

GTZ. 2010. GLOBALGAP Smallholder QMS Set-up Guide: How to establish a QMS in your group. (GTZ, 2010), http://www2.gtz.de/dokumente/bib-2010/gtz2010-0428en-globalgap-smallholderqms.pdf.

Gulbrandsen, Lars H. 2008. Accountability Arrangements in Non-State Standards Organizations: Instrumental Design and Imitation. Organization 15 (4):563-583.

Heise, Jenni, Kerstin Uhlig, and Laurent Vonwiller. 2007. The Grasp Project Report: Towards Good Social Practices in Agriculture: GLOBALGAP c/o FoodPLUS GmbH, Deutsche Gesellschaft für Technische Zusammenarbeit (GTZ) GmbH, Coop (Switzerland).

Hoffmann, Ulrich, and Rene Vossenaar. 2007. Codes for Good Agricultural Practices: Opportunities and Challenges for Fruit and Vegetable Exports from Latin American Developing Countries: Experiences of Argentina, Brazil and Costa Rica In UNCTAD/DITC/TED/2007/2: UNCTAD.

Hofmans, Willem. 1999. EUREP's Accomplishments to Date. In EUREPGAP Verification 2000, edited by K. Möller: EHI EuroHandelsinstitut Gmbh.

Hofmans, Willem, and Nigel Garbutt, eds. 2001. EUREPGAP: The Global Partnership for Safe and Sustainable Agriculture - Partnership 2001 Plus: EUREPGAP c/o FoodPLUS GmbH.

Leighton, Tommy. 2002. Krasemann Questions Eurep Gap: Kai Krasemann, President of Freshfel, Has Hit Out at the Commercial Integrity of Eurep Gap. Fresh Produce Journal (10th November 2002).

Leighton, Tommy. 2003. EurepGAP Must Deliver on Promises. Fresh Produce Journal (19th November 2003).

Leighton, Tommy. 2006. Garbutt Call for EurepGAP Unity. Fresh Produce Journal (6th October 2006). Meyer, John W. 2008. Reflections on Institutional Theories of Organizations. In The Sage Handbook of Organizational Institutionalism, edited by R. Greenwood, C. Oliver, R. Suddaby and K. Sahlin-Andersson: Sage

Möller, Kristian, ed. 1998a. Integrated Production of Fruit and Vegetables EHI EuroHandelsinstitut Gmbh.

Möller, Kristian. 1998b. The Euro-Retailer Produce Working Group EUREP. In Integrated Production of Fruit and Vegetables, edited by K. Möller: EHI EuroHandelsinstitut Gmbh.

Möller, Kristian. 2000. EUREP Info E-Mail 02/2000. Internet Archive, 24 April 2001, http://web.archive.org/web/20010424175559/http://www.eurep.org/arbeitskreise/seiten/ eurep-info-email-2-2000.htm.

Möller, Kristian. 2006. Economics of Standard Owners: Competition as Barrier to Global Harmonisation of Food Assurance Systems. In Quality Management in Food Chains edited by L. Theuvsen, A. Spiller, M. Peupert and G. Jahn: Wageningen Academic Publishers

Oliver, Christine. 1991. Strategic Responses to Institutional Processes. Academy of Management Review 16 (1):145-179.

Pache, Anne-Claire, and Filipe Santos. 2010. When Worlds Collide: The Internal Dynamics of Organizational Responses to Conflicting Institutional Demands. Academy of Management Review 35 (3):455-476. 
PIP/COLEACP. 2004. PIP Magazine. No 4 September 2004, http://pip.coleacp.org/files/documents/oct2004.pdf.

Richardson, Alan J, and Burkard Eberlein. 2011. Legitimating Transnational Standard Setting: The Case of the International Accounting Standards Board. Journal of Business Ethics 98:217-245.

Schleifer, Philip. 2015. Creating Legitimacy for Private Rules: Explaining the Choice of Legitimation Strategies in Transnational Non-State Governance. Robert Schuman Centre for Advanced Studies Research Paper No. RSCAS 2015/62, http://ssrn.com/abstract=2657068.

Scott, Colin. 1990. Continuity and Change in British Food Law. Modern Law Review 53 (6):785-801.

Scott, W Richard. 1987. The Adolescence of Institutional Theory Administrative Science Quarterly 32 (4):493-511.

Scott, W Richard. 1998. Organizations: Rational, Natural and Open Systems. 4th ed: Prentice-Hall. Suchman, Mark. 1995. Managing Legitimacy: Strategic and Institutional Approaches. Academy of Management Review 20 (3):571-610.

Suddaby, Roy, David J Cooper, and Royston Greenwood. 2007. Transnational Regulation of Professional Services: Governance Dynamics of Field Level Organizational Change Accounting, Organizations and Society 32 (4):333-362.

Tallontire, Anne, Valerie Nelson, Adrienne Martin, and Maggie Opondo. 2008. Governance and Agency in the Global Horticulture Chain : The Case of Global GAP. In European Association of Development Institutes General Conference: The Need For Policy Coherence and New Partnerships, Geneva, 24-28 June 2008.

Tallontire, Anne, Maggie Opondo, and Valerie Nelson. 2013. Contingent Spaces for Smallholder Participation in GlobalGAP: Insights from Kenyan Horticulture Value Chains. The Geographical Journal 180(4):353-364.

Tamm Hallström, Kristina, and Magnus Boström. 2010. Transnational Multi-Stakeholder Standardization: Organizing Fragile Non-State Authority: Edward Elgar.

Tamm Hallström, Kristina, and Ingrid Gustafsson. 2014. Value-Neutralizing in Verification Markets: Organizing for Independence Through Accreditation. In Configuring Value Conflicts in Markets, edited by S. Alexius and K. Tamm Hallström: Edward Elgar.

Tyler, Tom R. 2006. Psychological Perspectives on Legitimacy and Legitimation. Annual Review of Psychology 57:375-400.

UNCTAD. 2005. Division on International Trade in Goods and Services, and Commodities Activity Report 2004: Major Outputs and Lessons Learnt. In UNCTAD/DITC/MISC/2004/24, Note by UNCTAD Secretariat.

van der Grijp, Nicolien. 2008. Regulating Pesticide Risk Reduction: The Practice and Dynamics of Legal Pluralism. Ph.D Thesis Vrije Universiteit, Amsterdam.

van Mulekom, Leo, and Mathew Parr. 2007. Oxfam and IUCN NL: Pursuing Responsible Policies and Practices in the Supply Chain of Tropical Shrimps. GLOBALGAP Conference, Bangkok, 6-7 September 2007, Internet Archive 5 July 2010, http://web.archive.org/web/20100705054616/http://www.globalgap.org/cms/upload/Reso urces/Presentations/Bangkok/4_L_vanMulekom.pdf.

Wise, Christopher. 1998. The NFU-Retailer Partnership's 'Assured Produce' Scheme. In Integrated Production of Fruit and Vegetables, edited by K. Möller: EHI EuroHandelsinstitut Gmbh.

Wood, Stepan, Kenneth W. Abbott, Julia Black, Burkard Eberlein, and Errol Meidinger. 2015. The Interactive Dynamics of Transnational Business Governance: A Challenge for Transnational Legal Theory. Transnational Legal Theory 6 (2):333-369.

World Trade Organization 2005, Committee on Sanitary and Phytosanitary Measures, 'Summary of the Meeting Held on 29-30 June 2005: Note by Secretariat' G/SPS/R/37.

World Trade Organization 2006a, Committee on Sanitary and Phytosanitary Measures, 'Specific Trade Concerns: Issues Considered in 2006: Note by Secretariat - Addendum' G/SPS/GEN/204/Rev.7/Add.1. 
World Trade Organization 2006b, Committee on Sanitary and Phytosanitary Measures, 'Summary of the Meeting of 11-12 October 2006: Note by Secretariat' G/SPS/R/43.

World Trade Organization 2007a, Committee on Sanitary and Phytosanitary Measures, 'Private Sector Standards and Developing Countries Exports of Fresh Fruit and Vegetables: Communication from the United Nations Conference on Trade and Development (UNCTAD) 22 February 2007 G/SPS/GEN/761.

World Trade Organization 2007b, Committee on Sanitary and Phytosanitary Measures, 'Summary of the Meeting of 28-1 March 2007: Note by Secretariat' G/SPS/R/44. 